Quim. Nova, Vol. 34, No. 3, 404-407, 2011

\title{
DETERMINATION OF ALUMINUM IN FOOD SAMPLES AFTER PRECONCENTRATION AS ALUMINON COMPLEX ON MICROCRYSTALLINE NAPHTHALENE BY SPECTROPHOTOMETRY
}

\author{
Mohammad Reza Fathi, Nahid Pourreza* and Zeinab Ardan \\ Department of Chemistry, College of Science, Shahid Chamran University, Ahvaz, Iran
}

Recebido em 17/4/10; aceito em 10/10/10; publicado na web em 26/1/11

\begin{abstract}
A sensitive preconcentration procedure for spectrophotometeric determination of aluminum was developed. Aluminum as aluminon complex is adsorbed on microcrystalline naphthalene. The naphthalene containing the complex is dissolved in $3 \mathrm{~mL}$ of acetone and its absorbance is measured at $544 \mathrm{~nm}$. The effect of various factors on the preconcentration of aluminum was investigated. The calibration graph was linear in the range of 1-60 $\mathrm{g} \mathrm{L}^{-1}$. The limit of detection was $0.52 \mu \mathrm{g} \mathrm{L}^{-1}$ and relative standard deviation for the determination of $5 \mu \mathrm{g} \mathrm{L} \mathrm{L}^{-1}$ was $2.65 \%$. The proposed solid phase extraction procedure was applied to determination of aluminum in food samples.
\end{abstract}

Keywords: aluminum; preconcentration; food samples.

\section{INTRODUCTION}

Aluminum is a non essential element and toxic metal which is widespread throughout the environment. Some studies suggest that aluminum may be accumulated in the brain via different routes (drinking waters, food, and medicines) and interfere with the normal activities of nervous system. Aluminum causes problems for human health because this metal ion has been considered as a possible cause of renal osteodystrophy, Parkinson disease and Alzheimer's disease. ${ }^{1}$ Therefore determination of trace levels of aluminum in food and environmental samples is of great importance.

Various instrumental techniques have been used for the analysis of aluminum at trace levels. These include flame atomic absorption spectrometry, ${ }^{2}$ inductively coupled plasma - mass spectrometry (ICP-MS), ${ }^{3}$ inductively coupled plasma-atomic emission spectrometry (ICP-AES), ${ }^{4,5}$ graphite furnace atomic absorption spectrometry ${ }^{6}$ and spectrophotometery. ${ }^{7-10}$ ICP-MS and ICP-AES are expensive instruments with high costs of operation. ${ }^{11}$ Spectrophotometric methods are simple and low cost procedures that have been widely used for the determination of metal ions which could form a color complex with chromogenic reagents. ${ }^{12,13}$ However, sometimes the sensitivity is not good enough for the determination of low concentrations of aluminum and a preconcentration step is often required. Several methods for the separation and preconcentration of aluminum with extraction procedures have been reported, e.g., liquidliquid extraction, ${ }^{14}$ cloud point extraction ${ }^{15}$ liquid-liquid microextraction ${ }^{16}$ and solid phase extraction. ${ }^{17-19}$ Solid phase extraction (SPE) has several advantages over other preconcentration procedure including simplicity, low consumption of reagents, rapidity and high preconcentration factor. ${ }^{20} \mathrm{~A}$ variety of solid phase extractants such as Tiron modified resin, ${ }^{17}$ nanometer-sized titanium dioxide ${ }^{19}$ and naphthalene ${ }^{21}$ have been used for preconcentration and determination of trace amounts of aluminum.

In this paper a simple method with solid phase extraction is described for the determination of $\mathrm{Al}$ (III). Aluminon is used as a selective ligand for the formation of colored complex. This complex is retained on microcrystalline naphthalene in a mini column. The solid mass containing naphthalene and the retained complex is then dissolved in acetone and its absorbance is measured at $544 \mathrm{~nm}$.

\section{EXPERIMENTAL}

\section{Instruments}

A GBC Cintra 101, UV-Visible spectrophotometer (Australia) was used for absorbance measurements using $1 \mathrm{~cm}$ glass cells.

A digital pH-Meter model 632, Metrohm (Switzerland) with a combined glass electrode was used for $\mathrm{pH}$ adjustments. A Teb Azma vacuum pump (Iran) was used for setting the flow rate.

\section{Reagents}

All reagents were of analytical grade and the solutions were prepared with double distilled water. A stock solution of $1000 \mu \mathrm{g} \mathrm{mL} \mathrm{L}^{-1}$ of $\mathrm{Al}(\mathrm{III})$ was prepared by dissolving $1.38 \mathrm{~g}$ of $\mathrm{Al}(\mathrm{NO} 3)_{3} .9 \mathrm{H}_{2} \mathrm{O}$ (Merck) in $5 \mathrm{~mL}$ of concentrated $\mathrm{HNO}_{3}$ and diluted to $100 \mathrm{~mL}$. The working solutions were prepared by suitable dilution of the stock solution. An aluminon solution $\left(1 \times 10^{-3} \mathrm{~mol} \mathrm{~L}^{-1}\right)$ was prepared by dissolving 0.5 $\mathrm{g}$ of aluminon (Merck) in distilled water and diluting to $1000 \mathrm{~mL}$. A $0.2 \mathrm{~mol} \mathrm{~L}^{-1}$ of hydrochloric acid solution was prepared by diluting 8.3 $\mathrm{mL}$ of concentrated hydrochloric acid (Merck) to $500 \mathrm{~mL}$.

The microcrystalline naphthalene was prepared by dissolving $20 \mathrm{~g}$ of naphthalene in $60 \mathrm{~mL}$ of acetone on a stirrer.This solution was transferred to a breaker containing $1000 \mathrm{~mL}$ of distilled water at room temperature and then allowed to stand for $30 \mathrm{~min}$. The microcrystalline naphthalene slurry was then filtered on a filter paper, dried and stored in a glass bottle for further use.

\section{Preparation of naphthalene column}

A larger naphthalene crystal was placed at the bottom of glass column ( $7.0 \mathrm{~cm}$ long and $0.7 \mathrm{~cm}$ in diameter) in order to prevent the leakage of the adsorbent. Then $0.1 \mathrm{~g}$ of dried microcrystalline naphthalene as the adsorbent was poured into the glass column and slightly pressed in the column with a flat glass rod.

\section{Sample preparation}

$1.0 \mathrm{~g}$ of rice flour, wheat flour, tomato, onion, cabbage, squash 
and potato samples were first carbonized each, and then burned in the furnace at $700{ }^{\circ} \mathrm{C}$ for 3-4 h. After each residue was cooled to room temperature, it was extracted by heating in $1.0 \mathrm{~mL}$ of $6 \mathrm{~mol} \mathrm{~L}^{-1} \mathrm{HCl}$, filtered into a $100 \mathrm{~mL}$ volumetric flask..$^{22}$ This solution was treated under the general procedure. Five replicate measurements were performed for each sample. The recovery tests were also performed by adding known concentrations of aluminum solution to the samples. The percent recovery was calculated from the added and found values.

\section{Preconcentration procedure}

An aliquot of $\mathrm{Al}(\mathrm{III})$ stock solution (so that its final concentration would be in the range of 1-60 $\left.\mu \mathrm{g} \mathrm{L}^{-1}\right), 5 \mathrm{~mL}$ of $1 \times 10^{-3} \mathrm{~mol} \mathrm{~L}^{-1}$ of aluminon and $5 \mathrm{~mL}$ of $0.2 \mathrm{~mol} \mathrm{~L}^{-1}$ hydrochloric acid were added to 250 $\mathrm{mL}$ volumetric flask and diluted to $250 \mathrm{~mL}$ with water. The solution containing $\mathrm{Al}$ (III) complex was passed through the naphthalene colu$\mathrm{mn}$ at a flow rate $6 \mathrm{~mL} \mathrm{~min}^{-1}$. The naphthalene adsorbent containing the complex was dissolved in $3 \mathrm{~mL}$ of acetone and its absorbance was measured at $544 \mathrm{~nm}$. A blank solution was also run under the same experimental conditions without adding any aluminum.

\section{RESULTS AND DISCUSSION}

The preliminary experiments showed that Al-aluminon complex was effectively retained on microcrystalline naphthalene while the blank solution containing aluminon was not retained appreciably on this adsorbent. Therefore, the retention of this complex on naphthalene was used to develop a preconcentration procedure and spectrophotometric method for the determination of aluminum. The absorption spectrum of the solid mass containing naphthalene and Al-aluminon complex dissolved in acetone showed that maximum absorbance occurs at $544 \mathrm{~nm}$. Thus all the absorption measurements were performed at this wavelength.

\section{Effect of type and concentration of acid}

The effect of $\mathrm{HNO}_{3}$ and $\mathrm{HCl}$ as acids on the formation of $\mathrm{Al}-$ aluminon complex was studied. $\mathrm{HNO}_{3}$ was not suitable because it decreased the absorbance of $\mathrm{Al}$ complex. Therefore the effect of different concentrations of $\mathrm{HCl}$ in the range of $1 \times 10^{-3}$ to $7 \times 10^{-3}$ mol L $\mathrm{L}^{-1}$ was investigated. The results given in Figure 1 show that the absorbance of Al-aluminon complex was maximum in the range of $3 \times 10^{-3}$ to $5 \times 10^{-3} \mathrm{~mol} \mathrm{~L}^{-1}$ of $\mathrm{HCl}$. Thus, a concentration of $4 \times 10^{-3}$

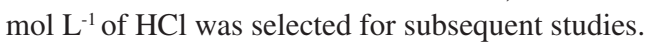

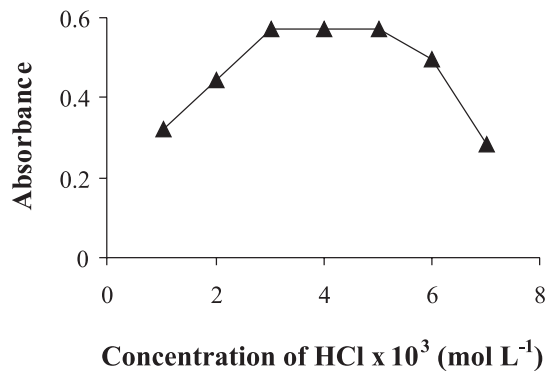

Figure 1. Effect of hydrochloric acid concentration on the absorbance of aluminum complex after solid phase extraction on naphthalene. Conditions: aluminon concentration $2.0 \times 10^{-5} \mathrm{~mol} \mathrm{~L}^{-1}$, sample volume $100 \mathrm{~mL}$, flow rate $6 \mathrm{~mL} \mathrm{~min} \mathrm{~m}^{-1}$; solvent $3 \mathrm{~mL}$ of acetone

\section{Effect of aluminon concentration}

The influence of aluminon concentration was also investigated in the range of $0.5 \times 10^{-5}$ to $4.0 \times 10^{-5} \mathrm{~mol} \mathrm{~L}^{-1}$. Figure 2 shows that the absorbance of $\mathrm{Al}$ complex was increased up to $1.0 \times 10^{-5} \mathrm{~mol} \mathrm{~L}^{-1}$ and remained constant above that. By increasing the reagent concentration, the complex is formed more completely and the absorbance is increased. When the complex formation is complete the absorbance becomes constant and reaches a plateau. Thus, a concentration of 2.0 $\mathrm{x} 10^{-5} \mathrm{~mol} \mathrm{~L}^{-1}$ where the complex formation is complete was selected as optimum concentration.

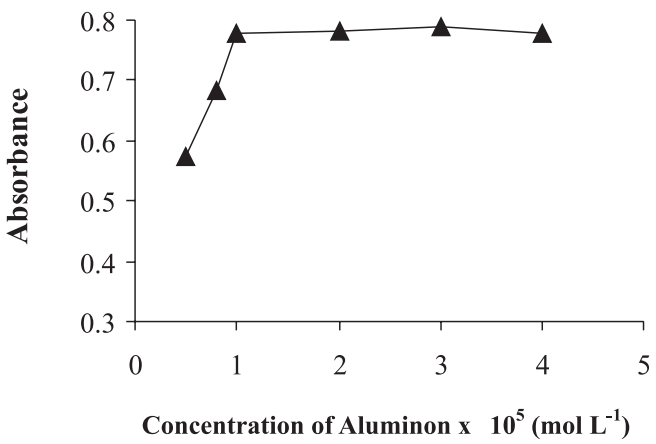

Figure 2. Effect of aluminon concentration on the absorbance of aluminum complex Hafter solid phase extraction on naphthalene. Conditions: hydrochloric acid concentration $4 \times 10^{-3} \mathrm{~mol} \mathrm{~L}^{-1}$; sample volume $100 \mathrm{~mL}$, flow rate

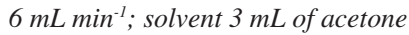

\section{Effect of solvent type and volume}

Various solvents such as acetone, chloroform, dichioromethane, dimethylsulfoxide, dimethylformamide, tetrahydrofuran and ethanol were examined for dissolving the microcrystalline naphthalene containing the complex. Chloroform and dichloromethane did not dissolve the aluminum complex and only dissolved the naphthalene sorbent. Ethanol and acetone dissolved the solid mass containing the complex but the color of the complex was not stable in ethanol. Therefore, acetone was selected as the dissolving solvent.

Different volumes of acetone in the range of 3-6 mL were used and $3 \mathrm{~mL}$ of acetone was selected for further work because it dissolved the adsorbent containing the complex completely. At higher volumes, the solution becomes more diluted and the absorbance is decreased. Lower volumes than $3 \mathrm{~mL}$ were not used because it does not dissolve the whole adsorbent containing complex.

\section{Effect of the amount of adsorbent}

The effect of amounts of microcrystalline naphthalene as the adsorbent was studied in the range of 0.05-0.20 g. The results showed that absorbance was increased when the amount of adsorbent was increased but at higher amounts than $0.1 \mathrm{~g}$, the blank readings are also increased. Thus $0.1 \mathrm{~g}$ of adsorbent was selected for further work. The higher amounts than $0.2 \mathrm{~g}$ were not tested because the adsorbent did not dissolve in $3 \mathrm{~mL}$ of solvent completely. The naphthalene crystals can be collected, recycled and used several times without loss in sensitivity.

\section{Effect of sample flow rate}

Sample flow rate is an important parameter to obtain quantitative retention of analyte ion. Thus the effect of sample solution flow rate on the retention of the complex was examined in the range of 2-12 mL $\mathrm{min}^{-1}$ using a pump. The results indicated that the flow rate of $4-7 \mathrm{~mL}$ $\min ^{-1}$ was suitable for retention of the complex on the naphthalene column because the absorbance of the eluted complex was constant. 
Therefore, a flow rate of $6 \mathrm{~mL} \mathrm{~min}^{-1}$ was selected as optimum flow rate. At higher flow rates there was a reduction in the absorbance of aluminum complex, because there is not sufficient contact time between the sample solution and naphthalene.

\section{Effect of sample volume}

In pre-concentration procedure is desired to achieve high breakthrough volumes and also high pre-concentration factor so that lower concentrations can be analyzed. Thus in order to determine maximum applicable volume of sample solution, the volume of the aqueous phase was varied from 100 to $500 \mathrm{~mL}$. All solutions contained $10 \mu \mathrm{g}$ of aluminum and $4 \times 10^{-3} \mathrm{~mol} \mathrm{~L}^{-1}$ of hydrochloric acid. The obtained results showed that the absorbance of aluminum complex was constant up to $500 \mathrm{~mL}$ sample volume but because higher volumes increased the analysis time, we used $250 \mathrm{~mL}$ of the sample volume for further work. Thus, a preconcentration factor 83.3 can be achieved when using $250 \mathrm{~mL}$ of the sample volume and dissolving the solid mass in $3 \mathrm{~mL}$ of acetone.

\section{Characteristics of the method}

The calibration graph was obtained using the proposed procedure for preconcentration of aluminum with a sample volume of $250 \mathrm{~mL}$. The calibration graph was linear in the range of $1-60 \mu \mathrm{g} \mathrm{L}^{-1}$ in the initial solution with an equation of $\mathrm{A}=0.019 \mathrm{C}+0.0043$, where $\mathrm{A}$ is the absorbance and $\mathrm{C}$ is aluminum concentration in $\mu \mathrm{g} \mathrm{L}^{-1}$. The regression coefficient for the line is $0.9993(n=10)$. The limit of detection calculated from three times the standard deviation of 12 blank solutions was $0.52 \mu \mathrm{g} \mathrm{L}^{-1}$ which is better or comparable to some of the previously reported methods..$^{2,-10,13,15}$ The relative standard deviation (R.S.D) for 10 replicate measurements of 5 and $40 \mu \mathrm{g} \mathrm{L}^{-1}$ by using general procedure was 2.65 and $1.06 \%$ respectively.

\section{Interference studies}

In order to examine the effect of different ions on the determination of $\mathrm{Al}$ (III), a constant amount of aluminum was taken with different amounts of ions and general procedure was followed. Any deviation of $5 \%$ or more from the absorbance value of the standard solution was considered as interference. Results given in Table 1 show that large number of ions tested have no effect on the determination of aluminum. Therefore, the proposed procedure is highly selective.

Table 1. Effect of interfering ions on the determination of $40 \mathrm{ng} \mathrm{mL}^{-1}$ of $\mathrm{Al}(\mathrm{III})$

\begin{tabular}{cc}
\hline Interfering ion & Tolerance ratio (w/w) \\
\hline $\mathrm{Ca}^{2+}, \mathrm{Mg}^{2+}, \mathrm{Na}^{+}, \mathrm{K}^{+}, \mathrm{Hg}^{2+}, \mathrm{Pb}^{2+}, \mathrm{I}^{-}, \mathrm{Cd}^{2+}, \mathrm{Tl}^{3+}$ & 1000 \\
$\mathrm{CO}_{3}{ }^{2-}, \mathrm{Co}^{2+}, \mathrm{Ni}^{2+}, \mathrm{Mn}^{2+}, \mathrm{Cr}^{3+}, \mathrm{Bi}^{3+}, \mathrm{NO}_{3}{ }^{-}$, & 700 \\
$\mathrm{SO}_{4}{ }^{2-}, \mathrm{Zn}^{2+}, \mathrm{Cu}^{2+}, \mathrm{PO}_{4}{ }^{3-}, \mathrm{HPO}_{4}{ }^{2-}$ & 500 \\
$\mathrm{Fe}^{2+}, \mathrm{Fe}^{3+}$ & 200 \\
$\mathrm{~F}^{-}$ & 20 \\
\hline
\end{tabular}

\section{APPLICATION}

The proposed procedure was applied to the determination of aluminum in food samples. Known amounts of aluminum were also spiked to food samples in order to perform recovery tests. The results are given in Table 2 . The results indicate the capability of the procedure in the determination of aluminum and good agreement was obtained between the added and measured analyte amounts. In order to validate the results potato and rice samples were analyzed by both the purposed procedure and ICP emission method (Table 3). There was no significant difference between the results at $95 \%$ confidence limit by performing t test.

Table 2. Determination of Al(III) in food samples under optimum conditions

\begin{tabular}{ccccc}
\hline Sample & $\begin{array}{c}\mathrm{Al}(\mathrm{III}) \text { added } \\
\left(\mu \mathrm{g} \mathrm{L}^{-1}\right)\end{array}$ & $\begin{array}{c}\mathrm{Al}(\mathrm{III}) \text { found }^{\mathrm{a}} \\
\left(\mu \mathrm{g} \mathrm{L}^{-1}\right)\end{array}$ & $\begin{array}{c}\text { Recovery } \\
(\%)\end{array}$ & $\begin{array}{c}\text { Amount of } \\
\mathrm{Al}(\mathrm{III})^{\mathrm{a}}\left(\mu \mathrm{g} \mathrm{g}^{-1}\right)\end{array}$ \\
\hline Tomato & - & $31.3 \pm 0.4$ & - & $0.8 \pm 0.1$ \\
& 15.0 & $46.0 \pm 0.6$ & 98.0 & \\
Onion & 20 & $50.5 \pm 0.6$ & 96.5 & \\
& 15 & $33.0 \pm 0.6$ & - & $4.1 \pm 0.2$ \\
& 20 & $53.2 \pm 0.6$ & 94.7 & \\
Squash & - & $33.6 \pm 0.4$ & - & $5.6 \pm 0.2$ \\
& & 15 & $49.6 \pm 0.5$ & 106.6 \\
& 20 & $54.0 \pm 0.6$ & 102.0 & \\
Cabbage & - & $36.4 \pm 0.4$ & - & $9.1 \pm 0.2$ \\
& 15 & $51.3 \pm 0.6$ & 99.3 & \\
& 20 & $56.8 \pm 0.7$ & 102.0 & \\
Rice flour & - & $24.1 \pm 0.4$ & - & $1.2 \pm 0.1$ \\
& 10 & $34.5 \pm 0.4$ & 104.0 & \\
& 20 & $44.0 \pm 0.5$ & 99.5 & \\
Wheat flour & - & $27.2 \pm 0.4$ & - & $3.4 \pm 0.2$ \\
& 15 & $43.5 \pm 0.5$ & 102.0 & \\
& 20 & $47.7 \pm 0.5$ & 102.5 & \\
\hline
\end{tabular}

a. $\bar{x} \pm$ ts $/ \sqrt{ } n$ at $95 \%$ confidence $(\mathrm{n}=5)$

Table 3. Determination of $\mathrm{Al}(\mathrm{III})$ in potato and rice sample and comparison with ICP method

\begin{tabular}{ccc}
\hline Sample & \multicolumn{2}{c}{ Amount of Al(III) $\left(\mu \mathrm{g} \mathrm{g}^{-1}\right)$} \\
\hline & Found by this procedure $^{\mathrm{a}}$ & Found by ICP $^{\mathrm{a}}$ \\
Potato & $3.18 \pm 0.15$ & $3.32 \pm 0.15$ \\
Rice flour & $1.20 \pm 0.10$ & $1.30 \pm 0.13$ \\
\hline
\end{tabular}

a. $\bar{x} \pm$ ts $/ \sqrt{ } n$ at $95 \%$ confidence $(\mathrm{n}=5)$

\section{CONCLUSION}

The results presented in this paper demonstrate the usefulness microcrystalline naphthalene for quantitative preconcentration of aluminum in different samples. The proposed procedure allows the determination of aluminum to be carried out at $\mu \mathrm{g} \mathrm{L}^{-1}$ levels. The procedure is a simple and efficient preconcentration procedure which uses a low cost adsorbent and gives low LOD and good selectivity with respect to some of the previously reported procedures. The solid phase extraction procedure was successfully applied to the monitoring of $\mathrm{Al}$ in various food samples with good accuracies.

\section{ACKNOWLEDGEMENT}

The authors wish to thank Shahid Chamran University Research Council for financial support of this work (Grant 1389).

\section{REFERENCES}

1. Sang, H.; Liang, P.; Du, D.; J. Hazard. Mater. 2008, 154, 1127. 
2. Safavi, A.; Momeni, S.; Saghar, N.; J. Hazard. Mater. 2009, 162, 333.

3. D'Ilio, S.; Violante, N.; Caimi, S.; Di Gregorio, M.; Petrucci, F.; Senofonte, O.; Anal. Chim. Acta 2006, 573-574, 432.

4. Luo, M. B.; Wu, H.; Zhang, J.; Lin, H.; Han, W. Y.; Bi, S. P.; Atom. Spectrosc. 2007, 28, 95.

5. Masson, P.; Talanta 2007, 71, 1399.

6. Narin, I.; Tuzen, M.; Soylak, M.; Talanta 2004, 63, 411.

7. Abbasi, A.; Farmany, A.; Gholivand, M. B.; Naghipour, A. F.; Abbasi, F.; Khani, H.; Food Chem. 2009, 116, 1019.

8. Matsumiya, H.; Iki, N.; Miyano, S.; Talanta 2004, 62, 337.

9. Nascimento, P. C.; Jost, C. L.; Guterres, M. V.; Del Fabro, L. D.; de Carvalho, L. M.; Bohrer, D.; Talanta 2006, 70, 540.

10. Li, Z.; Lu, N.; Zhou, X.; Song, Q.; J. Pharm. Biomed. Anal. 2007, 43, 1609.

11. Komarek, J.; Cervenka, R.; Ruzicka, T.; Kuban, V.; J. Pharm. Biomed. Anal. 2007, 45, 504.

12. Ni, Y.; Huang, C.; Kokot, S.; Anal. Chim. Acta 2007, 599, 209.
13. Huseyinli, A. A.; Alieva, R.; Haciyeva, S.; Güray, T.; J. Hazard.Mater. 2009, 163, 1001.

14. Zhang, J.; Xu, H.; Ren, J. L.; Anal. Chim. Acta 2000, 405, 31.

15. Bavili Tabrizi, A.; Food Chem. 2007, 100, 1698.

16. Rezaee, M.; Yamini, Y.; Khanchi, A.; Faraji, M.; Saleh, A.; J. Hazard. Mater. 2010, 178, 766.

17. Luo, M.; Bi, S.; J. Inorg. Biochem. 2003, 97, 173.

18. Luo, M. B.; Wu, H.; Zhang, J.; Chen, D.; Bi, S. P.; Sep. Sci. Technol. 2008, 43, 2225.

19. Matus, P.; Hagarova, I.; Bujdos, M.; Divis, P.; Kubova, J.; J. Inorg. Biochem. 2009, 103, 1473.

20. Ghaedi, M.; Ahmadi, F.; Tavakoli, Z.; Montazerozohori, M.; Khanmohammadi, A.; Soylak, M.; J. Hazard. Mater. 2008, 152, 248.

21. Pourreza, N.; Behpour, M.; Microchem. J. 1999, 6, 250.

22. Ma, Q.; Cao, Q.-E.; Zhao, Y.; Wua, Sh.; Hua, Zh.; Xu, Q.; Food Chem. 2000, 71, 123 . 